\title{
PENGARUH SISTEM INFORMASI MANAJEMEN, PELAYANAN, DAN KEPEMIMPINAN TERHADAP INDEKS KEPUASAN MASYARAKAT DI KOTA TANGERANG
}

\author{
Farid Bintoro Aji; Edi Abdurachman \\ Mathematics \& Statistics Department, School of Computer Science, Binus University \\ Jl. K.H. Syahdan No. 9, Palmerah, Jakarta Barat 11480 \\ edia@binus.edu
}

\begin{abstract}
As a public service provider the government faces a lot of problems associated with the improvement of public service quality through excellent service performance and high quality service products. Leadership factor also plays an important role in service organizations to ensure the effectiveness of the organization. Based on earlier ideas, a research is conducted towards the trade business license service delivery by local government of Tangerang which focuses on aspects of information systems management, service performance, and leadership in relation to the level of community satisfaction. There are several methods of data collection and information, such as questionnaires, interviews, field observation and literature study. The data collected were analyzed using the method of regression analysis, correlation analysis, and chi square test. The analysis showed that there is a significant relationship between the variables of the study. Therefore, it can be concluded that management information systems, service performance, and leadership has significant effects on the level of community satisfaction.
\end{abstract}

Keywords: public services, management information systems, service performance, leadership, community satisfaction

\begin{abstract}
ABSTRAK
Sebagai penyedia layanan publik pemerintah dihadapkan pada banyak permasalahan berkaitan dengan peningkatan kualitas pelayanan publik melalui kinerja pelayanan yang baik dan produk-produk layanan yang berkualitas. Faktor kepemimpinan juga berperan penting pada organisasi pelayanan untuk menjamin efektivitas penyelenggaraan organisasi. Berdasarkan pemikiran-pemikiran tadi, dilakukan penelitian penyelenggaraan pelayanan ijin usaha perdagangan oleh pemerintah daerah kota Tangerang yang berfokus pada aspek sistem informasi manajemen, kinerja pelayanan, kepemimpinan dalam hubungannya dengan tingkat kepuasan masyarakat. Terdapat beberapa metode pengumpulan data dan informasi, di antaranya penyebaran kuesioner, wawancara, observasi lapangan, dan studi kepustakaan. Data yang berhasil dikumpulkan dianalisis menggunakan metode analisis regresi, analisis korelasi, dan uji chi square test. Hasil analisis menunjukkan bahwa terdapat hubungan yang signifikan antara variabel-variabel penelitian. Sehingga dapat disimpulkan bahwa sistem informasi manajemen, kinerja pelayanan, kepemimpinan memiliki pengaruh yang signifikan terhadap tingkat kepuasan masyarakat.
\end{abstract}

Kata kunci: pelayanan publik, sistem informasi manajemen, kinerja pelayanan, kepemimpinan, kepuasan masyarakat 


\section{PENDAHULUAN}

Globalisasi mendorong pemanfaatan teknologi informasi diberbagai bidang bisnis. Perkembangan tersebut akhirnya mendesak pemerintah mempercepat implementasi suatu sistem yang disebut e-government (electronic government). Menurut Ndraha (2003), pemerintahan yang dalam perspektif ilmu pemerintahan didefinisikan sebagai badan yang berfungsi memproses pemenuhan kebutuhan manusia sebagai pelanggan baik berupa produk-produk ataupun jasa layanan publik dan layanan sipil, dewasa ini dihadapkan pada banyak permasalahan mendasar yang tidak lain berkaitan dengan tuntutan reformasi birokrasi dari berbagai pihak, dan khususnya tuntutan akan peningkatan kualitas pelayanan publik. Pemerintah sesungguhnya telah mengeluarkan peraturan pemerintah tentang e-government.

Keseluruhan bentuk pelayanan yang disediakan pemerintah selaku penyedia pelayanan tersebut, menuntut kinerja organisasi pelayanan secara baik, dan produk layanan yang berkualitas dengan dimensi-dimensi berupa kemudahan, kecepatan, ketepatan, dan keadilan serta memberikan rasa keamanan dari aspek legitimasi yang diberikan dan sekaligus sebagai jaminan dari produk layanan pemerintah. Namun demikian, dewasa ini masyarakat umumnya masih merasa kurang puas terhadap layanan yang diberikan oleh instansi pemerintah. Hal ini dilihat dari banyaknya keluhan masyarakat antara lain, pelayanannya lambat, tidak sederhana, memerlukan waktu yang cukup lama, cenderung tidak efesien, cenderung high cost, bahkan masyarakat ada yang menganggap pelayanan cenderung dipersulit.

Dalam rangka mencari solusi terhadap berbagai permasalahan pelayanan tersebut di atas, dilakukan suatu studi untuk mengetahui faktor-faktor apa saja yang berpengaruh secara signifikan terhadap kinerja pelayanan instansi pemerintah. Penelitian dilaksanakan melalui survei terhadap penyelenggaraan pelayanan ijin usaha perdagangan yang disediakan oleh pemerintah daerah (selaku penyedia jasa layanan) dengan fokus penelitian terhadap aspek sistem informasi manajemen, tingkat kinerja pelayanan, kepemimpinan organisasi, jenis pelayanan, dan tingkat kepuasan masyarakat melalui capaian indeks kepuasan masyarakat, dengan lokus pelayanan masyarakat pemerintah Kota Tangerang. Dari hasil studi kasus ini diharapkan dapat direkomendasikan berbagai hal yang harus dilakukan dalam rangka peningkatan kualitas pelayanan instansi pemerintah.

Bertolak dari latar belakang, focus dan locus penelitian, maka pertanyaan penelitian dapat dirumuskan sebagai berikut: (1) apakah terdapat pengaruh implementasi sistem informasi manajemen, kinerja pelayanan, kepemimpinan dalam proses pemberian pelayanan publik bagi masyarakat menurut jenis layanan baik secara parsial maupun secara simultan terhadap kepuasan masyarakat selaku penerima layanan di kota Tangerang? (2) bagaimana pengaruh implementasi sistem informasi manajemen, kinerja pelayanan, kepemimpinan dalam proses pemberian pelayanan publik bagi masyarakat menurut jenis layanan baik secara parsial maupun secara simultan terhadap kepuasan masyarakat selaku penerima layanan di kota Tangerang?

\section{Landasan Teori}

\section{Sistem Informasi Manajemen}

Davis dan Olson (1985) mengemukakan bahwa sistem merupakan keseluruhan yang kompleks dan teratur, suatu rancangan atau gabungan dari bagian yang membentuk suatu kesatuan menyeluruh. Untuk memberikan gambaran konseptual komunikasi informasi yang berkualitas, perlu memiliki ukuran tentang informasi itu sendiri. Seperti dikemukakan Supriyono (2008) bahwa ukuran untuk mengetahui berkualitas atau tidaknya informasi bersifat: (1) akurat - benar dan sesuai realitas; (2) 
tepat waktu - tidak terlambat dan baru serta masih segar; (3) relevan - informasi yang bermanfaat bagi pemakainya merupakan koreksi terhadap informasi sebelumnya.

Dalam setiap organisasi, informasi merupakan bahan pokok bagi pembuatan keputusan. Informasi dapat menyokong penuh bagi pembuatan keputusan apabila berlangsung dalam sebuah sistem. Kebutuhan organisasi dalam sistem informasi berkaitan dengan teknik pengumpulan, pengolahan, penyimpanan, dan dengan mudah menemukan kembali saat diperlukan serta penyaluran informasi. Sebuah sistem informasi melakukan semua pengolahan transaksi yang perlu untuk organisasi serta memberikan dukungan informasi dan pengolahan untuk fungsi manajemen termasuk dalam hal pengambilan keputusan. Sistem informasi yang terintegrasi merupakan sebuah sistem yang menghubungan layanan front office dan back office dalam satu mata ratai sistem. Manfaat sebuah sistem yang teintegrasi adalah menurunkan biaya koordinasi, biaya proses, kecepatan waktu pemrosesan dan keakuratan serta kehandalan data yang diproses. Hasil keluaran dari sebuah implementasi pengembangan sistem informasi manajemen (SIM) dapat ditinjau melalui sisi proses pengembangan, biaya pengembangan, kegunaan dan fitur-fitur yang disediakan oleh sebuah SIM, sistem operasi pendukung sistemnya, dan keterintegrasian sistem. Terintegrasinya sistem informasi menjadi kunci agar peningkatan kualitas pelayanan dapat dicapai secara berkesinambungan. Oleh karena itu, dengan pengembangan sistem infomasi manajemen diharapkan meningkatkan kinerja pelayanan pemerintah dan indeks kepuasan masyarakat (IKM) dari waktu ke waktu.

\section{Tingkat Kinerja Pelayanan}

Kinerja atau sering dikenal sebagai performance berkaitan dengan pengelolaan atau manajemen suatu organisasi dalam upaya mencapai tujuan yang telah disepakati. Karena kinerja berkaitan dengan kepengelolaan, istilah manajemen kinerja seringkali dijumpai jika dibandingkan dengan istilah kinerja secara parsial. Manajemen kinerja merupakan salah satu kebutuhan bagi setiap organisasi untuk dijalankan dengan mengutamakan bentuk kerjasama dalam organisasi secara harmonis dan terpadu terhadap penyelenggara organisasi baik sebagai pimpinan maupun sebagai bawahan, dengan orientasi kepada proses pelaksanaan dan hasil serta evaluasi yang dicapai.

Menurut Parasuraman, Zeithaml dan Berry (1988), kepuasan akan jasa layanan publik dipengaruhi oleh beberapa faktor yaitu: (1) kualitas jenis layanan; (2) kualitas pelayanan, yang dipersepsikan lima dimensi ukuran servqual yaitu: bukti nyata (tangible), kehandalan (reliability), daya tanggap (responsiveness), keyakinan (assurance), dan kepedulian (emphaty); (3) faktor emosional; (4) kepuasan harga/biaya layanan dan (5) biaya dan kemudahan.

Kepuasan pengguna akan jasa layanan akan meningkat apabila persepsi pengguna layanan akan seluruh atau sebagian unsur-unsur tersebut meningkat (memenuhi harapan/expectation). Menurut Albrecht \& Zemke (2001), kualitas pelayanan publik merupakan hasil interaksi berbagai aspek, yaitu sistem pelayanan, sumber daya manusia, sumber pelayanan, strategi dan pengguna jasa layanan/pelanggan. Pengukuran kinerja dilakukan untuk mengetahui apakah terdapat deviasi antara progress yang direncanakan dengan kenyataan. Apabila terdapat deviasi berupa progress yang lebih rendah, perlu dilakukan langkah-langkah untuk memacu kegiatan agar tujuan yang diharapkan dapat dicapai. Seberapa jauh tujuan tersebut dapat dicapai mencerminkan hasil kerja atau prestasi kerja dan seringkali dinyatakan sebagai kinerja organisasi dan menunjukkan performa organisasi. Hasil kerja organisasi dapat sama dengan tujuan yang ditetapkan, tapi dapat pula lebih besar atau bahkan lebih kecil dari harapan.

\section{Kepemimpinan}

Kepemimpinan diperlukan manusia karena adanya keterbatasan dan kelebihan-kelebihan tertentu pada manusia. Di satu pihak manusia terbatas kemampuannya untuk memimpin, di pihak lain ada orang yang mempunyai kelebihan kemampuan untuk memimpin. Di sinilah awal timbulnya 
pemimpin dan kepemimpinan. Konsep dan pengertian kepemimpinan kadangkala diartikan sebagai pelaksanaan otorita dan pembuatan keputusan dan sebagai suatu bentuk inisiatip untuk bertindak dan menhasilkan suatu pola yang konsisten dalam rangka mencari jalan pemecahan dari suatu persoalan bersama (Hemphill, 2010).

Namun, pengertian kepemimpinan yang banyak kita ketahui seperti yang dikemukakan Terry (1982) dalam bukunya Principle of Management, sebagai kegiatan atau aktivitas untuk mempengaruhi orang-orang supaya diarahkan mencapai tujuan organisasi. Jika dikaitkan dengan pendapat pakarpakar tersebut di atas, secara sederhana dapat dikemukakan bahwa dalam suatu organsisasi terdapat struktur dan hirarki yang berada pada level atas adalah juga berfungsi sebagai pimpinan atau pemimpin. Dalam konsep kepemimpinan terdapat model kepemimpinan kontijensi yang dikembangkan oleh Fiedler dan Garcia (1987). Model ini berisi tentang hubungan gaya kepemimpinan dengan situasi yang menyenangkan.

Dimensi-dimensi tersebut merupakan dimensi yang penting untuk menimbulkan situasi menyenangkan. Dengan ketentuan semakin tinggi dimensi-dimensi tersebut maka semakin tinggi menyenangkan situasi dalam kepemimpinan organisasi. Dengan kata lain suatu situasi akan menyenangkan jika: (1) pemimpin diterima oleh para pengikutnya (derajat dimensi pertama tinggi); (2) tugas-tugas dan semua yang berhubungan dengannya ditentukan dengan jelas (derajat dimensi kedua tinggi); (3) penggunaan otoritas dan kekuasaan secara formal diterapkan pada posisi pemimpin (derajat dimensi ketiga juga tinggi). Demikian halnya jika terjadi sebaliknya, akan terjadi situasi yang tidak menyenangkan. Dalam situasi yang menyenangkan, roda organisasi akan berjalan secara efektif karena didukung dengan regulasi atau ketentuan secara baik dan para pengikut dengan setia mengikuti segala arahan yang disampaikan pemimpin.

\section{Kepuasan Masyarakat}

Tse dan Wilton (1988) mendefinisikan kepuasan pelanggan (pengguna layanan pada layanan publik) sebagai respon pengguna layanan terhadap evaluasi ketidaksesuaian (disconfirmation) yang dipersepsikan dan kinerja actual yang dirasakan dan diterima oleh pengguna jasa layanan. Model yang digunakan untuk mengukur kualitas pelayanan yang akan dikembangkan dalam penelitian ini adalah model Parasuraman, Zeithaml dan Berry (PZB) (Parasuraman, Zeuthaml, Berry, 1985) dikenal dengan SERVQUAL, yang menekankan pada lima gap: (1) gap harapan dan persepsi manajemen perusahaan; (2) gap persepsi manajemen terhadap harapan pengguna jasa layanan dan spesifikasi kualitas layanan; (3) gap antara spesifikasi kualitas layanan dengan penyampaian layanan; (4) gap antara penyampaian dan komunikasi eksternal; (5) gap antara layanan yang dirasakan dan jasa yang diberikan. Kinerja pelayanan akan ditentukan oleh persepsi kepuasan pengguna jasa layanan. Oleh karena itu, kinerja layanan dipengaruhi oleh birokrasi, mekanisme pasar, dan lembaga swadaya masyarakat Ouchi (1981).

Dalam ketentuan yang dikeluarkan Menpan terdapat unsur minimal yang harus ada untuk dasar pengukuran indeks kepuasan masyarakat sebagai berikut: (1) prosedur pelayanan, yaitu kemudahan pelayanan yang kepada masyarakat dilihat dari sisi kesederhanaan alur pelayanan; (2) persyaratan pelayanan, yaitu persyaratan teknis dan administratif yang diperlukan untuk mendapatkan pelayanan sesuai dengan jenis pelayanannya; (3) kejelasan petugas pelayanan, yaitu keberadaan dan kepastian petugas yang memberikan pelayanan (nama, jabatan serta kewenangan dan tanggung jawabnya); (4) kedisiplinan petugas pelayanan, yaitu kesungguhan petugas dalam memberikan pelayanan terutama terhadap konsistensi waktu kerja sesuai ketentuan yang berlaku; (5) tanggung jawab petugas pelayanan, yaitu kejelasan wewenang dan tanggung jawab petugas dalam penyelenggaraan dan penyelesaian pelayanan; (6) kemampuan petugas pelayanan, yaitu tingkat keahlian dan ketrampilan yang dimiliki petugas dalam memberikan/menyelesaikan pelayanan kepada masyarakat; (7) kecepatan pelayanan, yaitu target waktu pelayanan dapat diselesaikan dalam waktu yang telah ditentukan oleh unit penyelenggara pelayanan; (8) keadilan mendapatkan pelayanan, yaitu 
pelaksanaan pelayanan dengan tidak membedakan golongan/status masyarakat yang dilayani; (9) kesopanan dan keramahan petugas, yaitu sikap petugas dalam memberikan pelayanan kepada masyarakat secara sopan dan ramah; (10) kewajaran biaya pelayanan, yaitu keterjangkauan masyarakat terhadap besarnya biaya yang ditetapkan oleh unit pelayanan; (11) kepastian biaya pelayanan, yaitu kesesuaian antara biaya yang dibayarkan dengan biaya yang telah ditetapkan; (12) kepastian jadwal pelayanan, yaitu pelaksanaan waktu pelayanan, sesuai dengan ketentuan yang telah ditetapkan; (13) kenyamanan lingkungan, yaitu kondisi sarana dan prasarana pelayanan yang bersih, rapi, dan teratur sehingga dapat memberikan rasa nyaman kepada penerima pelayanan; (14) keamanan pelayanan, yaitu terjaminnya tingkat keamanan lingkungan unit pelayanan.

\section{METODE}

\section{Desain Penelitian}

Penelitian ini dimaksudkan untuk menguji jawaban rasional sehingga dapat menjelaskan fenomena yang menjadi masalah. Peneliti menggunakan desain penelitian tersebut karena tidak hanya menggambarkan dan menjelaskan fakta empirik yang ditemui di lapangan tetapi juga melakukan analisis pengaruh baik secara parsial maupun simultan antara variabel satu dengan variabel lainnya. Dalam tulisan ini dianalisis implementasi sistem informasi manajemen, kinerja pelayanan dan kepemimpinan pemerintah daerah serta jenis Surat Ijin Usaha Perdagangan (SIUP) terhadap indeks kepuasan masyarakat di Kota Tangerang. Untuk mendukung hipotesis dalam tulisan ini maka disebarkan kuesioner-kuesioner sejumlah sampel yang dibutuhkan pada dinas yang terkait di berbagai kecamatan di kabupaten Tangerang.

\section{Teknik Penarikan Sampel}

Jumlah sampel ditentukan dengan menggunakan teknik restricted sample, yaitu sampel ditarik dari populasi yang telah dikelompokkan lebih dahulu (Nazir, 1999). Dengan populasi yang telah dibatasi terhadap individu-individu warga masyarakat sebagai pengguna jasa pelayanan surat ijin usaha perdagangan dalam wilayah kota Tangerang yang berjumlah 1.998 orang. Selanjutnya ditentukan besarnya ukuran sampel dengan menggunakan rumus Slovin (Sugiyono, 2003) diperoleh ukuran sampel sebanyak 297 warga masyarakat.

\section{Prosedur dan Teknik Pengumpulan Data}

Data primer penelitian ini adalah berbagai informasi yang diterima langsung dari responden terpilih secara lisan, maupun tertulis melalui penyebaran kuesioner yang menyangkut tentang suatu masalah yang berkaitan dengan variabel penelitian. Sedangkan data sekunder penelitian ini adalah berbagai informasi yang diterima tentang suatu kenyataan atau masalah empirik dari responden dimana informasi tersebut telah tersusun dan diolah secara tertulis, yang meliputi komposisi aparat, keadaan penduduk, fungsi dan tugas pokok, dan struktur organisasi, serta dokumen lainnya yang berkaitan.

Teknik pengumpulan data dilakukan dengan teknik sebagai berikut: (1) kuesioner menyebarkan daftar pertanyaan yang bersifat tertutup; (2) wawancara - mengajukan beberapa pertanyaan secara langsung terhadap responden; (3) observasi - mengamati dan merekam secara langsung terhadap gejala-gejala yang berhubungan dengan variabel penelitian yang berlangsung di Kota Tangerang; (4) studi kepustakaan - melihat dan mempelajari berbagai bahan bacaan, buku teoritis, makalah ilmiah, jurnal, dokumen dan laporan yang berkaitan dengan variabel penelitian. 


\section{Hipotesis Penelitian}

Untuk mengetahui faktor apa saja yang berpengaruh secara signifikan terhadap kepuasan masyarakat, diajukan beberapa hipotesis berikut: (1) implementasi sistem informasi berpengaruh signifikan terhadap kepuasan masyarakat; (2) baik tidaknya kinerja pelayanan berpengaruh secara signifikan terhadap kepuasan masyarakat; (3) kualitas kepemimpinan dari suatu instansi pemerintah berpengaruh secara signifikan terhadap kepuasan masyarakat yang menerima pelayanan dari instansi tersebut; (4) skala usaha, jenis usaha dan cakupan usaha berpengaruh signifikan dalam pemberian penilaian oleh perusahaan tersebut dalam kaitannya dengan kepuasan pelayanan dari instansi publik yang melayaninya.

\section{HASIL DAN PEMBAHASAN}

\section{Uji Validitas Instrumen Penelitian}

Hasil perhitungan melalui SPPS melalui metode Corrected Item-Total Correction, semua item atau indicator yang dijadikan butir-butir untuk mengukur variabel semuanya valid. Hasil uji tersebut disajikan pada Tabel 1.

Tabel 1

Hasil Uji Validitas Butir-butir pada Setiap Variabel

\begin{tabular}{lcc}
\hline \multicolumn{1}{c}{ Nama Variabel } & Jumlah Pertanyaan & Kesimpulan \\
\hline Sistem Informasi Manajemen & 13 & Valid \\
Kinerja pelayanan & 18 & Valid \\
Kepemimpinan & 10 & Valid \\
kepuasan masyarakat & 15 & Valid \\
\hline
\end{tabular}

\section{Uji Reliabilitas Instrumen Penelitian}

Hasil output SPSS dengan melalui melalui metode uji reliabilitas Cronbach's Alpha, dapat dilihat pada Tabel 2 berikut.

Tabel 2

Hasil Uji Reliabilitas untuk Berbagai Variabel

\begin{tabular}{llccc}
\hline No & \multicolumn{1}{c}{$\begin{array}{c}\text { Item Pertanyaan } \\
\text { Variabel }\end{array}$} & $\begin{array}{c}\text { Nilai Cronbach's } \\
\text { Alpha }\end{array}$ & $\begin{array}{c}\text { Batas Nilai } \\
\text { Cronbach's Alpha }\end{array}$ & Kesimpulan \\
\hline 1 & Implementasi Sistem & 0,77 & 0,60 & Reliable \\
& Informasi Manajemen & & & \\
2 & Kinerja Pelayanan & 0,76 & 0,60 & Reliable \\
3 & Kepemimpinan & 0,88 & 0,60 & Reliable \\
4 & Kepuasan Masyarakat & 0,93 & 0,60 & Reliable \\
\hline
\end{tabular}

\section{Pengujian Hipotesis}

Dalam penelitian ini, digunakan analisis regresi, yang di dalamnya digunakan koefisien korelasi dan regresi. Selain itu digunakan juga determinasi untuk mengetahui seberapa besar sumbangan (pengaruh) variabel yaitu Implementasi Sistem Informasi Manajemen (X1) beserta 
dimensi-dimensinya, Kinerja Pelayanan (X2) beserta dimensi-dimensinya, Kepemimpinan (X3) beserta dimensi-dimensinya terhadap Variabel Kepuasan Masyarakat (Y). Hasil pengolahan data melalui SPSS tentang hubungan pengaruh secara parsial variabel Implementasi Sistem Informasi Manajemen, Kinerja Pelayanan, dan Kepemimpinan terhadap kepuasan masyarakat dalam penyelenggaraan pelayanan surat ijin usaha perdagangan di kota Tangerang dapat dilihat pada Tabel 3 di bawah ini:

Tabel 3

Uji Individual Koefisien Regresi

\begin{tabular}{|c|c|c|c|c|}
\hline \multirow{2}{*}{ Model } & Standardized Coe & cients & \multirow{2}{*}{ t } & \\
\hline & Beta & & & \\
\hline SIM & & .125 & 1.978 & .004 \\
\hline K.P & & .123 & 3.897 & .000 \\
\hline Kepemimpinan & & .707 & 11.313 & .000 \\
\hline
\end{tabular}

a. Dependent Variable: Kepuasan Masyarakat

Dari Table 3 bisa dilihat bahwa ternyata secara individual masing-masing variabel yaitu Tingkat implementasi penerapan SIM, Kinerja pelayanan dan Kepemimpinan berpengaruh sangat signifikan terhadap kepuasan masyarakat terhadap instansi pelayanan publik. Hal ini dapat dilihat dari tingkat signifikan levelnya yang untuk semua variabel lebih kecil dari taraf uji $\alpha=0.01$. Sehingga berdasarkan hasil penelitian tersebut, dapat dibuat suatu diagram yang menggambarkan pengaruh variabel Implementasi Sistem Informasi Manajemen, Kinerja Pelayanan dan Kepemimpinan terhadap Kepuasan Masyarakat (Gambar 1).

\section{Uji Chi Square Test}

Setelah melakukan perhitungan menggunakan bantuan perangkat lunak SPSS, didapatkan suatu hasil perhitungan yang menggambarkan ada atau tidaknya hubungan antara variabel-variabel dapat dituangkan ke dalam Tabel 4.

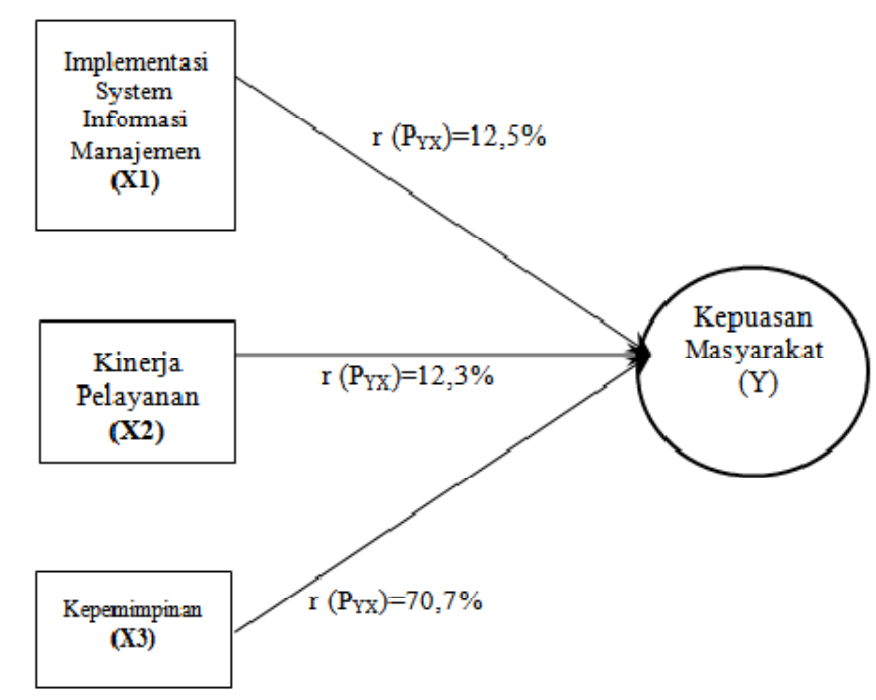

Gambar 1. Diagram pengaruh variabel implementasi sistem informasi manajemen, kinerja pelayanan dan kepemimpinan terhadap kepuasan masyarakat. 
Tabel 4

Uji Chi-Kuadrat untuk Mengetahui ada Tidaknya Hubungan antara Variabel Demografi Perusahaan dengan Berbagai Variabel dalam Model

\begin{tabular}{lcccc}
\hline & Kepuasan Masyarakat & Kinerja Pelayanan & Kepemimpinan & Sistem Informasi manajemen \\
\hline Skala Usaha & Ya & Ya & Tidak & Ya \\
Jenis Usaha & Ya & Ya & Yidak & Ya \\
Cakupan Usaha & Ya & Ya & Tida \\
\hline
\end{tabular}

\section{KESIMPULAN DAN SARAN}

\section{Kesimpulan} berikut.

Berdasarkan hasil analisis data dan hasil pengujian hipotesis, dapat ditarik kesimpulan sebagai

Pertama, unit layanan publik yang menggunakan sistem informasi manajemen memiliki pengaruh langsung terhadap kepuasan masyarakat dalam pelayanan surat ijin usaha perdagangan (SIUP). Dengan kata lain terjadinya perubahan sistem informasi manajemen semakin baik akan mempengaruhi kepuasan masyarakat yang semakin baik.

Kedua, kinerja pelayanan unit layanan publik juga berpengaruh langsung terhadap kepuasan masyarakat dalam penyelenggaraan pelayanan SIUP. Hal ini dapat diartikan bahwa terjadinya perubahan kinerja pelayanan yang semakin baik akan mempengaruhi kepuasan masyarakat yang semakin baik pula.

Ketiga, kepemimpinan pada unit layanan publik berpengaruh langsung terhadap kepuasan masyarakat dalam penyelenggaraan pelayanan SIUP. Jadi, dapat disimpulkan bahwa kepemimpinan terhadap unit pelayanan publik yang semakin baik akan mempengaruhi kepuasan masyarakat yang semakin baik pula.

Keempat, besarnya skala usaha dan cakupan usaha suatu perusahaan tidak mutlak menuntut kepemimpinan yang baik dari suatu entitas. Sehingga disimpulkan bahwa responden di dalam penelitian ini tidak terlalu peduli dan memperhatikan faktor kepemimpinan sebagai salah satu variabel yang mempengaruhi kepuasan masyarakat.

\section{Saran}

Untuk memaksimalkan penerapan sistim informasi manajemen secara terintegrasi, perlu pengembangan kemampuan SDM aparatur secara terus menerus. Melalui aktivitas-aktivitas berikut ini: (1) pelatihan-pelatihan rutin yang berkaitan prosedur penggunaan sistem informasi; (2) sosialisasi antar aparat negara sehingga penyebaran pengetahuan merata; (3) melakukan penyuluhan untuk memberikan informasi kepada pelanggan akan keuntungan-keuntungan yang didapatkan melalui implementasi sistem informasi.

Untuk meningkatkan kinerja pelayanan, disarankan setiap pegawai yang bersentuhan langsung dengan proses pelayanan (front line officer) agar menguasai prosedur dan mekanisme kerja. Melalui: (1) penetapan peraturan daerah yang dapat dijadikan pedoman bagi setiap aparat negara yang melayani masyarakat; (2) sosialisasi terhadap peraturan pemerintah daerah yang ditetapkan. 
Disarankan agar pemimpin memiliki kesadaran untuk lebih mengenal keseluruhan tugas organisasi dalam memberikan pelayanan, mengenal keluhan-keluhan bawahannya, dan berkomunikasi dengan pelanggan melalui: (1) pelatihan dasar-dasar kepemimpinan yang dibutuhkan; (2) seleksi fit and proper test (uji tes kelayakan) untuk menjaring kandidat-kandidat yang memang berkompeten dalam memimpin; (3) pembuatan pernyataan (pakta) yang diucapkan lisan dan tertuang dalam tulisan tentang komitmen menjalankan kepemimpinan secara bersih dan akuntabel.

Penelitian selanjutnya disarankan untuk mendalami lebih lanjut bagaimana peranan masyarakat dalam meningkatan kualitas pelayanan itu sendiri dengan tetap berpatokan kepada tujuan akhir pelayanan yaitu peningkatan kepuasan masyarakat dalam hal pelayanan publik.

Sehubungan dengan perbedaan karakteristik setiap daerah satu dengan yang lain, penulis menyadari hasil penelitian yang didapatkan di kota Tangerang belum tentu dapat diaplikasikan kepada daerah-daerah lainnya yang memiliki karakteristik berbeda dengan kota yang penulis teliti. Untuk itu penulis menyarankan penelitian selanjutnya melakukan penelitian lebih lanjut dengan lingkup penelitian beberapa kota yang memiliki beraneka ragam karakteristik usaha, sehingga dapat diambil kesimpulan dari perbandingan beberapa kota tersebut.

Faktor kompetensi sangatlah mempengaruhi kemampuan seseorang dalam memimpin organisasinya. Ketika seseorang dikatakan tidak memiliki kompetensi yang cukup, sementara ia ditempatkan di posisi puncak, kemungkinan orang tersebut akan kesulitan untuk mengembangkan oranisasi yang dipimpinnya. Dengan mempertimbangkan tingkat pengaruh kompetensi terhadap kepemimpinan, penulis menyarankan agar penelitian selanjutnya menambah sebuah variabel penelitian tambahan yaitu kompetensi.

\section{DAFTAR PUSTAKA}

Albrecht. K. \& Zemke, R. (2001). Service America in the New Economy, (2nd ed.). New york: McGraw Hill.

Davis, G. B. \& Olson, M. H. (2009). Management Information Systems: Conceptual, Foundation, Structure and Development. New York: Mc Graw Hill.

Fiedler, F. E. \& Garcia, J. E. (1987). New Approach to Leadership, Cognitive Resources and Organizational Performance. New York: John Wiley and Sons.

Hemphill, P. L. (2010). Why You Are Already a Leader, ( ${ }^{\text {nd }}$ ed.). One White Pond Press.

Nazir, M. (1999). Metode Penelitian. Jakarta: Ghalia Indonesia.

Ndraha, Taliziduhu. (2003). Kybernology (Ilmu Pemerintahan Baru) 1 \& 2. Jakarta: Rineka Cipta.

Ouchi, W. (1981). Theory Z: How American Management Can Meet Japanese Challenge. New York: Addison Wesley.

Parasuraman A., Zeithaml V. A, dan Berry, Leonard, L. (1988). Servqual: A Multiple Item Scale for Measuring Customer Perception of Service Quality. Journal of Retailing, 64. 
RI. (2003). Surat Keputusan Menteri Pendayagunaan Aparatur Negara Nomor: 63/KEP/M.PAN/7/2003 tentang Pedoman Umum Penyelenggara Pelayanan Publik. Jakarta: Kementerian Pendayagunaan Aparatur Negara.

Sugiyono. (2003). Metode Penelitian Bisnis. Bandung: Tarsito.

Supriyono. 2008. Analisis Pengaruh Kompetensi Tenaga Penjualan dan Kualitas Jasa Logistik Terhadap Loyalitas Pelanggan. Semarang: Universitas Diponegoro.

Terry, G. R. (1982). Principles of Management. Mishawaka, USA: Irwin Publishing.

Tse, D. K. \& Wilton, P. C. (1988). Models for Consumer Satisfaction: An Extension. Journal of Marketing Research, 25, May. 